\title{
POPULATION STATUS OF JAGUARS (PANTHERA ONCA) AND PUMAS (PUMA CONCOLOR) IN NORTHEASTERN SONORA, MEXICO
}

\author{
OCTAVIO C. ROSAS-ROSAS ${ }^{1}$ \& LOUIS C. BENDER ${ }^{2}$ \\ ${ }^{1}$ Department of Biology, New Mexico State University, Las Cruces, NM 88003, U.S.A. \\ Present Address: Programa de Manejo y Conservación de Fauna Silvestre, Colegio de Postgraduados, \\ Campus San Luis Potosí, Iturbide No. 73, Salinas de Hidalgo, C.P. 78600, San Luis Potosí, MÉXICO. \\ Corresponding author: <octaviocrr@colpos.mx> \\ ${ }^{2}$ Extension Animal Sciences and Natural Resources, New Mexico State University, PO Box 30003 \\ MSC 4901, Las Cruces, New Mexico 88003, USA. <lbender@nmsu.edu>
}

Rosas-Rosas, O. C. \& L. C. Bender. 2012. Population status of jaguars (Panthera onca) and pumas (Puma concolor) in northeastern Sonora, Mexico. Acta Zoológica Mexicana (n. s.), 28(1): 86-101. ABSTRACT. Jaguars are endangered in Mexico and the United States, necessitating careful monitoring of population status. We determined minimum numbers of jaguars and sympatric pumas in a small population in northern Sonora, Mexico, the nearest known breeding population to the United States, by photographic captures supplemented by idiosyncratic features of tracks from track surveys (1999-2005). We also developed a discriminant function to differentiate species (jaguar v. puma) and sexes within species, which also aided in individual identification. Photographic captures identified 5 individual jaguars; this estimate was increased to 12 using idiosyncratic features and discriminant analysis of tracks. Jaguar kittens were only detected by track surveys. All jaguars identified by photographs were previously detected by tracks, but most (7 of 12) known from tracks were not captured in photographs. Jaguar presence was fluid; we identified 6 individual jaguars from 1999-2003, but only 3 of these were still present in 2004. We documented 4 new individuals during 2005, when none of the previously identified jaguars were detected. Similarly, we identified 14 individual pumas by tracks, but only 11 of these were captured in photographs. Four hindfoot measurements varied among species and sexes of jaguars and pumas, and these measurements were able to correctly classify $85-97 \%$ of tracks to the correct species and sex. Due to the high turnover of this jaguar population, which is at its fringe of the jaguar range in North America, we recommend constant monitoring of population status with camera traps and track surveys. If only limited resources are available, we recommend monitoring only with track surveys because they detected a greater number of individuals and all age classes of individuals.

Key words: Camera trap, Density, Jaguar, Mexico, Panthera onca, Puma concolor, Population status, Sonora, Track identification.

Rosas-Rosas, O. C. \& L. C. Bender. 2012. Estado de la población de jaguares (Panthera onca) y pumas (Puma concolor) en el noreste de Sonora, México. Acta Zoológica Mexicana (n. s.), 28(1): 86-101.

Recibido: 21/02/2011; aceptado: 15/09/2011. 
RESUMEN. El jaguar se encuentra enlistado en peligro de extinción en México y los Estados Unidos. Por esta razón esta especie necesita monitoreos cuidadosos del estado de su población. El presente estudio se condujo en una región con una pequeña población de jaguares, que es la población reproductiva conocida más cercana a los Estados Unidos. En el noreste de Sonora, México, se determinó el número mínimo de jaguares y pumas simpátricos, por medio de capturas fotográficas, complementado por medio de rastreo de huellas y características idiosincráticas de las mismas (1999-2005). Desarrollamos un análisis discriminante que nos ayudó a diferenciar entre jaguares y pumas, además del sexo entre ambos y sirvió también de apoyo para diferenciarlos individualmente. Por medio de capturas fotográficas se identificaron 5 jaguares; esta estimación se incrementó a 12 jaguares usando características idiosincráticas y un análisis discriminante de las huellas. Los cachorros de jaguar sólo fueron detectados por el rastreo de huellas. Todos los jaguares que se identificaron por medio de fotografías fueron previamente identificados por huellas, pero la mayoría ( 7 de 12) que se conocieron por huellas no fueron capturados fotográficamente. La presencia del jaguar fue cambiante; se identificaron 6 individuos de 1999-2003, pero sólo 3 de éstos estuvieron presentes en 2004. Se documentaron 4 nuevos individuos durante 2005 y ninguno de los previamente identificados se volvió a detectar. De la misma forma se identificaron 14 pumas por medio de huellas pero solo 11 se detectaron por medio de capturas fotográficas. Se utilizaron 4 medidas de las patas que variaron entre especies y sexo de jaguares y pumas. Este análisis de medidas permitió clasificar correctamente del $85-97 \%$ de las huellas de la especie correcta y de la especie correcta y su sexo. Debido al cambio notorio de esta población de jaguar, la cual se encuentra en el límite de su rango de distribución en Norteamérica, se recomienda un constante monitoreo del estado de la población con trampeo fotográfico y rastreo de huellas. Si los recursos son limitados entonces se recomienda rastreo de huellas debido a que en esta región se detectaron un mayor número de individuos de todas las clases de edad.

Palabras clave: Trampas fotográficas, Densidad, Jaguar, México, Panthera onca, Puma concolor, Estado de la población, Sonora, Identificación de huellas.

\section{INTRODUCTION}

Jaguars (Panthera onca) are endangered in Mexico and the United States (Federal Register 1997, SEMARNAT 2001). Recently, individual jaguars have been detected in the American southwest (Glenn 1996, McCain \& Childs 2008), and these likely came from a breeding population located about $200 \mathrm{~km}$ south of the Sonora-Arizona border (Rosas-Rosas et al. 2008, 2010). However, jaguars are rare in northeastern Sonora, probably due to excessive harvest of prey species, illegal killing for predator control, and habitat degradation (López-González \& Brown 2002, Rosas-Rosas et al. 2008, Rosas-Rosas et al. 2010 ). The concurrent presence of pumas (Puma concolor) further complicates viability of jaguars in northeastern Sonora, as many puma kills of livestock are attributed to jaguars, increasing the chances of illegal killing of jaguars (Rosas-Rosas et al. 2008).

Determining abundance trends is necessary to monitor the status of endangered jaguars. Most commonly, track surveys (Smallwood \& Fitzhugh 1993, Beier \& Cunningham 1996, Riordan 1998, Rosas-Rosas et al. 2003, Sharma et al. 2005, IsasiCatalá \& Barreto 2008) and capture-recapture models including radio-telemetry and camera-trapping (Hornocker 1969, Schaller \& Crawshaw 1980, Rabinowitz \& Not- 
tingham 1986, Karanth 1995, Logan et al. 1996, Karanth \& Nichols 1998, Silver et al. 2004, Karanth et al. 2004, Ceballos et al. 2007) have been used to estimate numbers and trends of large felids. Each of these methods has significant advantages and limitations. Individual identification by tracks has been criticized as being inaccurate and inadequate to provide information on distribution patterns, relative abundance, and density of large felids, mostly because of a tendency to overestimate minimum numbers, especially if not rigorously conducted (Karanth et al. 2003, Miller 2004, Isasi-Catalá \& Barreto 2008). Similarly, camera trapping has failed to identify all components of the population, especially juveniles (Karanth \& Nichols 2002).

Despite these limitations, each method has provided useful data for monitoring populations. Camera trapping has successfully identified minimum numbers of adults in multiple locations (Karanth \& Nichols 1998, Salom-Pérez et al. 2007, Faller et al. 2007). Similarly, Isasi-Catalá \& Barreto (2008) successfully identified individual jaguars by their tracks. Both methods allow recognition of individual behavior and habitat use; in addition, tracking allows identification of travel routes and territorial markings. Ultimately, however, no single technique used in large felid work has been adequately validated and each has several ecologically problematic assumptions (Karanth \& Nichols 1998, Karanth et al. 2003). Consequently, using multiple techniques to corroborate population status is important not only to produce acceptable estimates, but also to serve as an independent validation of existing techniques. Additionally, multiple techniques allow violations of assumptions of individual techniques and statistical power limitations present in all techniques to be overcome through corroboration (Salmon 1979).

Consequently, we used camera-trapping photographic surveys supplemented by track surveys to determine the minimum number of jaguars and pumas in the area around Nacori Chico, Sonora, Mexico, a population of key conservation status because it is the northernmost breeding population of jaguars in North America. Our objective was to identify individual jaguar and pumas by photographic captures and track characteristics in order to estimate minimum numbers of jaguars and pumas in our study area.

\section{Study area}

Our study area was located in northeastern Sonora in the foothills of northern Sierra Madre Occidental, the largest mountain range in western Mexico (Figure 1). The Sierra Madre Occidental encompasses a variety of habitats, including pine (Pinus spp.) forest, oak (Quercus spp.) woodlands, semitropical thornscrub, and tropical deciduous forest (Brown 1982). Topography is rocky and rugged with several intermittent and perennial streams. Precipitation ranges from about $400 \mathrm{~mm}$ annually in the valleys to over $1000 \mathrm{~mm}$ in higher elevations (Marshall 1957). Seasons included a dry season 


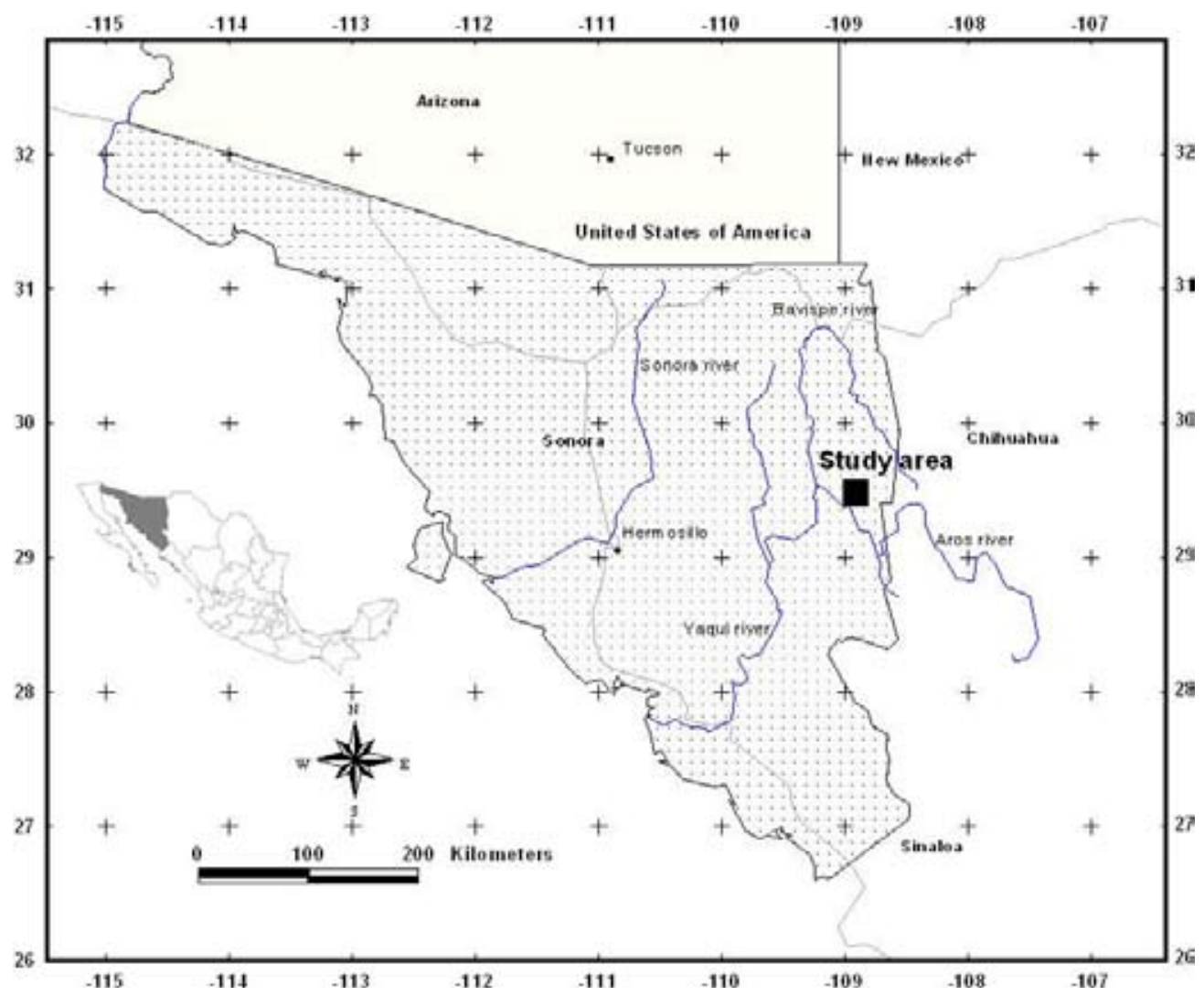

Figure 1. Jaguar study area located in the municipality of Nacori Chico, northeastern Sonora, Mexico, about $200 \mathrm{~km}$ south the United States-Mexico border.

(October-June) and a wet season (July-September), with the latter characterized by monsoonal rains (relatively frequent short duration, high intensity downpours).

Our study site encompassed approximately $400 \mathrm{~km}^{2}$ including 16 private ranches and was located about $30 \mathrm{~km}$ southwest of the town of Nacori Chico. Elevations ranged from $500-1500 \mathrm{~m}$. The main economic activity within the site is cattle ranching. Potential prey for jaguars and pumas included white-tailed deer, antelope jackrabbit (Lepus spp.), cottontail (Sylvilagus audubonii), coatimundi (Nasua narica), collared peccary (Pecari tajacu), opossum (Didelphis spp.), and cattle. Other carnivores present include coyote (Canis latrans), gray fox (Urocyon cinereoargenteus), raccoon (Procyon lotor), bobcat (Lynx rufus), ocelot (Leopardus pardalis), skunks (Mephitis macroura, Spilogale putorius, Conepatus mesoleucus), ring-tailed cat (Bassariscus astutus), badger (Taxidea taxus), and river otter (Lontra longicaudis) (Hall 1981). 


\section{MATERIALS AND METHODS}

Camera-trap surveys. During a reconnaissance survey, we conducted limited camera-trapping (Silver et al. 2004) from 2000-2004 primarily to determine jaguar presence or absence in our study area. For this survey, we placed one-sided camera-traps in areas we had previously detected jaguar and puma sign (fresh tracks, scrapes, raked trees, and fresh kills). We rotated 6 cameras (2 TrailMaster ${ }^{\circledR}$ TM-1500 [Goodson Associates Incorporated, Lenexa, Kansas, USA] and 4 CamTrakkers ${ }^{\circledR}$ [Cam Trak South Incorporated, Georgia, USA]) throughout our study site. We ran cameras for approximately 30 days in the same location, then moved cameras to different locations. This allowed us to cover 30 sites in our study area from May-July. We identified individual jaguars by spot-rosette variation of their pelage (Silver et al. 2004). For pumas we identified individuals using unique characteristics of individuals including scars, tail fractures, tadpoles, and body shape (Kelly et al. 2008). We also collected frontfoot and hindfoot tracks for both species from track traps at each camera station and used these to aid in identification of individual animals (see Track Surveys below).

In February 2005, we established a systematic camera trap grid to estimate the minimum number of jaguars in the study area. We ran camera traps from 9 February-9 April, 2005, using 42 CamTrakker and 24 DeerCam (DeerCam ${ }^{\circledR}$, Saint Paul, Minnesota, USA) passive infrared systems. We placed 26 camera trap stations in areas where jaguars were previously photographed and in areas where jaguar detection was maximized, such as near raked trees and where fresh jaguar tracks and feces had previously been found along roads, trails or washes. We spaced camera traps approximately 3-4 km apart, which corresponded to the home-range size of jaguars in Chamela-Cuixmala Biosphere Reserve in Jalisco, west Mexico. There, female jaguars had home ranges of $25 \mathrm{~km}^{2}$ during the dry season and $65 \mathrm{~km}^{2}$ during the wet season (Nuñez et al. 2002). The habitat conditions in Jalisco are similar to the habitat conditions in northeastern Sonora: semi-tropical thornscrub and tropical deciduous forest as dominant vegetation types with marked dry and wet seasons.

We placed two cameras at each station, one on each side of each site, to ensure that a photograph was taken of both sides of the jaguar and for redundancy in case of camera failure. We positioned cameras approximately $40 \mathrm{~cm}$ above the ground and attached cameras to a tree or branch. We faced cameras slightly down the trail to prevent mutual interference, set cameras to shoot simultaneously (Silver et al. 2004), and aligned cameras to where a track trap was placed. We operated camera traps for 60 days using 24 exposure ASA $40035-\mathrm{mm}$ film, and we visited cameras every 7-10 days to ensure they were functioning. Lastly, we placed track traps directly between cameras and also $300 \mathrm{~m}$ up and down the trail. We used data from both the reconnaissance surveys and the 2005 camera-trapping grid to identify individual jaguars and pumas in the study area. 
Track surveys. We conducted track surveys throughout the study area from July 1999-March 2005 during the dry and wet seasons of each year. Surveys were mainly conducted along washes, dirt roads, cattle trails, game trails, canyons and track plates. Once we identified positively a jaguar or puma track (Aranda 2000) we collected (made plaster casts, photographed) tracks and recorded location, vegetation type, elevation, and substrate. For analysis, we included tracks only if collected under the following criteria: 1) the surface of the terrain was flat; 2) the imprint was on loose dirt or silt substrate (no sand or mud); and 3) at least 1 front and 1 hindfoot track was collected. We collected tracks with plaster casts. We recorded 4 measurements from plaster casts of each hindfoot: total length (TL), total width (TW), total pad length (TPL), and total pad width (TPW) (Figure 2). We used MANOVA (Morrison 1990) to test whether hindfoot measurements of adult jaguars and pumas differed by species and gender. We also used linear discriminant analysis (Morrison 1990) to see whether these measures could differentiate tracks by species and genders. We also explored the ability of the resultant discriminant function to identify individual jaguars and pumas.

Additionally, we classified tracks by species and sex according to their shape and size, and differentiated individuals by different idiosyncratic diagnostic characteristics of their frontfoot tracks following the criteria of Rosas-Rosas et al. (2003) where

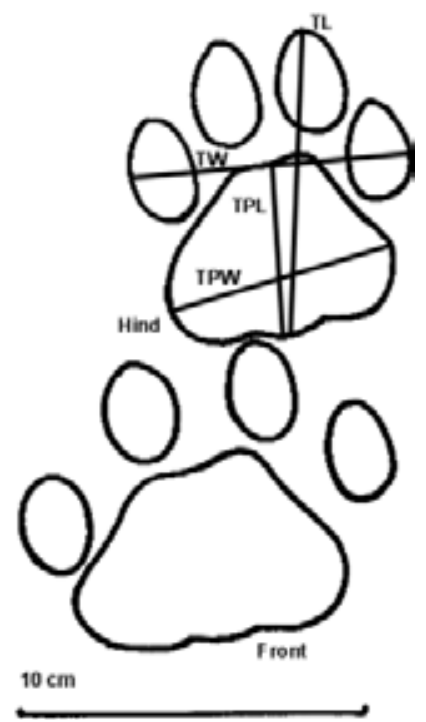

Figure 2. Four basic measurements including total length (TL), total width (TW), total pad length (TPL), and total pad width (TPW) of hindfeet that were used to differentiate between species and genders of jaguars and pumas. 
possible. Idiosyncratic features included displaced toes, pad shape, scars, etc. We used this data to supplement photographic captures in individual identification.

\section{RESULTS}

Camera-trap surveys. We identified 5 individual jaguars by photographic captures using spot-rosette patterns, including 4 adult males and 1 adult female (Table 1). Three jaguars ( 2 adult males, 1 adult female) were identified during 2000-2003 and 2 ( 2 adult males) during 2005.

We also identified 11 individual pumas ( 7 adult males, 4 adult females) by photographic captures (Table 2). Although individual pumas were more difficult to identify by photographic captures, size differences between males and females were obvious in photographs, and in 2 cases, pumas could be differentiated based on scars on their faces and ears (Kelly et al. 2008). Tracks were also useful to corroborate identification of individuals, especially pumas that did not show unique markings (see below).

Track surveys. We collected 208 jaguar tracks including 105 from a hindfoot and 103 from a frontfoot, 1999-2005. We identified 12 individual jaguars by idiosyncratic features of their frontfeet (including displaced toes and disfigured pads; Table 1), including 4 adult males (Figure 3), 6 adult females (Figure 4), and 2 kittens. Eight of these ( 2 adult males and 4 adult females, including 2 with 1 kitten each) were present from 1999-2003, but only 3 remained in 2004 (Table 1). During 2005, we identified 2 new adult males and 2 new adult females; none of the previously identified jaguars were present on the area in 2005. Identification of 5 individuals (4 adult males, 1 adult female) was corroborated by photographic captures (Table 1). Conversely, we

Table 1. Individual adult male, adult female, and juvenile jaguars identified from track characteristics and photographs, 1999-2005. Numbers correspond to the same individual (i.e., M1 = M1 through years and technique) and kittens are referenced to their mother.

\begin{tabular}{|c|c|c|c|c|c|c|}
\hline \multirow[b]{2}{*}{ Year } & \multicolumn{3}{|c|}{ Tracks } & \multicolumn{3}{|c|}{ Photographs } \\
\hline & Males & Females & Kittens & Males & Females & Kittens \\
\hline 1999 & M1 & $\mathrm{F} 1, \mathrm{~F} 2$ & & & & \\
\hline 2000 & M1, M2 & $\begin{array}{c}\mathrm{F} 1, \mathrm{~F} 2, \mathrm{~F} 3, \\
\mathrm{~F} 4\end{array}$ & $\begin{array}{l}\text { K1(F3) } \\
\text { K2(F4) }\end{array}$ & M1, M2 & & \\
\hline 2001 & M1, M2 & $\mathrm{F} 1, \mathrm{~F} 2, \mathrm{~F} 3$, & & M1 & & \\
\hline 2002 & M1 & $\mathrm{F} 1, \mathrm{~F} 3, \mathrm{~F} 4$ & & M1 & & \\
\hline 2003 & M1 & $\mathrm{F} 2, \mathrm{~F} 3$ & & M1 & F3 & \\
\hline 2004 & M1 & F3, F4 & & & & \\
\hline 2005 & M3, M4 & F5, F6 & & M3, M4 & & \\
\hline
\end{tabular}


Table 2. Individual adult male, adult female, and juvenile pumas identified from track characteristics and photographs, 1999-2005. Numbers correspond to the same individual (i.e., M1 = M1 through years and technique) and kittens are referenced to their mother.

Same for puma.

\begin{tabular}{ccccccc}
\hline & \multicolumn{2}{c}{ Tracks } & \multicolumn{3}{c}{ Photographs } \\
Year & Males & Females & Kittens & Males & Females & Kittens \\
\hline 1999 & M1, M2 & F1 & & M1 & F1 \\
2000 & M1, M2 & F2, & K1(F2) & M2 & \\
2001 & M1, M2, M3, M4 & F2, F3 & & \\
2002 & M3 & F3, F4 & M3 & \\
2003 & M3, M4 & F4 & & M4 & \\
2004 & M3, M5, M6 & F3, F4, F5 & K2(F4) & M4 & F3 \\
2005 & M1, M5, M6, M7 & F4, F5 & & M4, M5, M6, M7 & F4, F5 \\
\hline
\end{tabular}
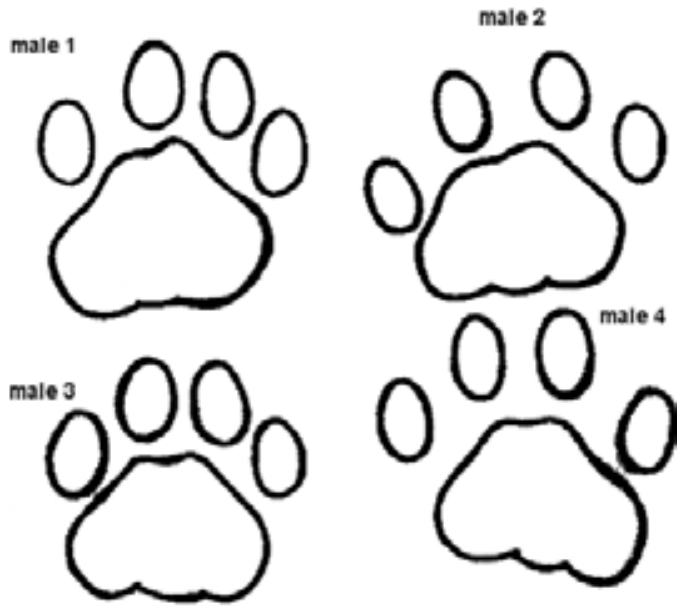

$10 \mathrm{~cm}$

Figure 3. Diagnostic track characteristics found consistently and used to differentiate 4 male jaguars in northeastern Sonora, Mexico. Note the comparative differences in the width of the front pad and distance between toes and main pad.

photographed all adult males that were identified by tracks, but only 1 of 6 known adult females and no kittens (Table 1). During our study, males showed a periodicity of approximately 30 days and females about 20 days between return visits to the same area. 


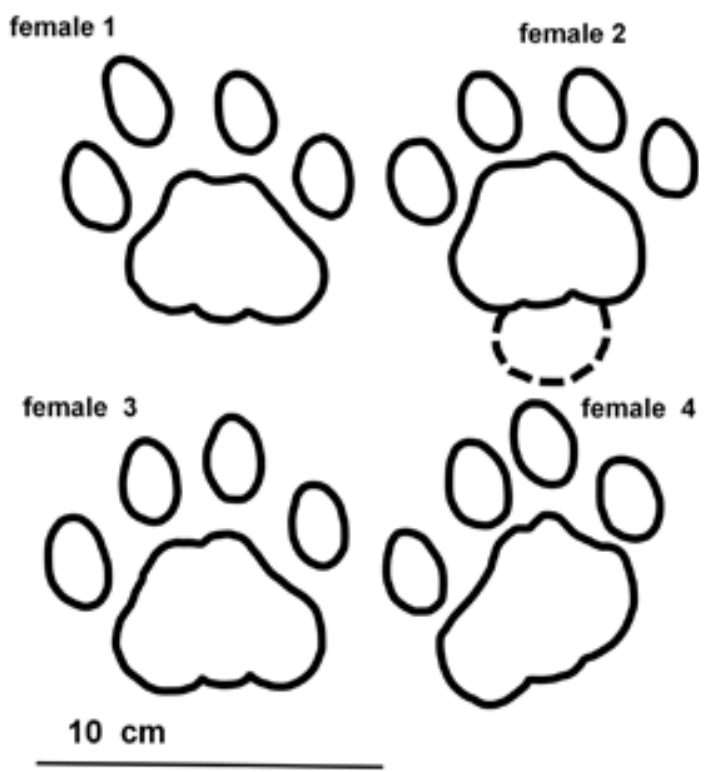

Figure 4. Diagnostic characteristics of tracks of 4 individual female jaguars. Note the leading out of place toe of female 1 , the calluses in the rear of the pad of female 2 , and the oblong main pad of female 4 compared to the rounder shape of female 3 .

Female 3 can also be differentiated by the shape of the pad.

We also collected 159 puma tracks, including 97 hindfoot and 62 frontfoot tracks. We identified a minimum of 14 different pumas from track features, including 7 males, 5 females, and 2 kittens (Table 2). Eleven of these ( 7 adult males, 4 adult females) were corroborated by photographs (Table 2). Similar to jaguars, all adult male pumas identified by track characteristics were also photographed, while only 4 of 5 adult females identified by track characteristics and no kittens were photographed (Table 2).

Hindfoot measurements of adult jaguars and pumas varied $\left(F_{12,514}=44.7 ; p<\right.$ $0.0001)$ by species and sex in TL $\left(F_{3,197}=117.7 ; p<0.0001\right)$, TW $\left(F_{3,197}=45.8 ; p<\right.$ $0.0001)$, TPL $\left(F_{3,197}=70.9 ; p<0.0001\right)$, and TPW $\left(F_{3,197}=86.5 ; p<0.0001\right)$ (Table $3)$. Jaguar males, jaguar females, puma males, and puma females each differed in TPL $(p<0.0001)$ and TPW $(p<0.037)$. Similarly, each sex and species differed in TL ( $p$ $<0.0004)$ except for jaguar and puma females which were similar $(p=0.351)$ and in TW $(p<0.0003)$ except for jaguar and puma males, which were similar $(p=0.495)$ (Table 3). Discriminant functions correctly classified $90.9 \%$ and $93.1 \%$ of male and female jaguar tracks, and $85.2 \%$ and $97.0 \%$ of male and female puma tracks. When we pooled both species into the same dataset, the resultant discriminant functions 
Table 3. Means (SE) total length (TL), total width (TW), total pad length (TPL), and total pad width (TPW) in mm of hindfeet tracks from of adult jaguars and pumas, northeastern Sonora, Mexico.

\begin{tabular}{ccccccc}
\hline Species & Sex & TL & TW & TPL & TPW & N \\
\hline Jaguar & Male & $90.9(0.8) \mathrm{B}$ & $83.1(1.3) \mathrm{A}$ & $51.7(0.6) \mathrm{A}$ & $63.8(0.8) \mathrm{A}$ & 33 \\
Jaguar & Female & $80.3(0.4) \mathrm{C}$ & $73.3(0.7) \mathrm{B}$ & $43.5(0.4) \mathrm{C}$ & $54.5(0.4) \mathrm{C}$ & 72 \\
Puma & Male & $94.7(0.9) \mathrm{A}$ & $82.0(0.9) \mathrm{A}$ & $47.5(0.5) \mathrm{B}$ & $56.7(0.6) \mathrm{B}$ & 63 \\
Puma & Female & $81.3(0.6) \mathrm{C}$ & $68.1(1.1) \mathrm{C}$ & $40.1(0.6) \mathrm{D}$ & $47.5(0.7) \mathrm{D}$ & 43 \\
\hline
\end{tabular}

had a total successful classification of $87.8 \%$ and $84.9 \%$ for male and female jaguars and $73.7 \%$ and $82.3 \%$ for male and female pumas, respectively. In a further analysis to explore the ability of the discriminant function to identify individual jaguars and pumas, the discriminant function correctly identified all individual male jaguars ( 4 of 4), 5 of 7 male pumas (two were incorrectly identified as 2 different female jaguars), 5 of 6 female jaguars (one individual was incorrectly identified as a female puma), and 5 of 5 female pumas as identified by tracks and photographs, supporting individual identifications from these methods.

Jaguar and puma density. Including an exterior buffer of $1 / 2$ the mean home range of adult female jaguar (Nuñez et al. 2002, Karanth \& Nichols 2002), our camera grid covered a total area of approximately $360 \mathrm{~km}^{2}$ for 1560 trap nights, February 9thApril 9th, 2005. We documented a minimum of 4 jaguars ( 2 adult males from both tracks and photographs; 2 adult females from tracks) and 6 pumas ( 3 adult males and 2 adult females from both tracks and photographs; 1 adult male from tracks) in 2005 from combined track identification and photographic captures. A minimum density estimate for jaguars was $1.1 / 100 \mathrm{~km}^{2}\left(4 / 360 \mathrm{~km}^{2}\right)$, assuming each adult male has a home range that overlaps exclusively with at least 1 female (Schaller \& Crawshaw 1980). Similarly, puma density from track and camera surveys was estimated at $1.7 / 100 \mathrm{~km}^{2}$.

\section{DISCUSSION}

Camera-trapping has received considerable recent support (Karanth et al. 2004, Ceballos et al. 2007, Salom-Pérez et al. 2007) and can be useful for monitoring large felid populations, but it has limitations. Logistical problems related to monitoring camera-traps in remote areas characterized by rugged topography were the most common problems we encountered. Topography, cattle, long distances between camera stations, and the lack of roads were the main constraints for checking and maintaining cameras. It was difficult to conduct camera-trapping in areas occupied by cattle because cattle triggered numerous cameras. On 3 occasions jaguars, as evidenced by tracks, could not have been photographed because cattle triggered most of the expo- 
sures before the jaguar moved between the cameras. Also, cameras were not completely effective in photographing individuals at traps; 2 jaguars and 5 pumas stepped on track traps but were not detected by cameras and, as seen elsewhere, kittens were never photographed (Karanth \& Nichols 2002). There were similar difficulties with track surveys; the same logistical problems applied to monitoring track plates and surveys, and identification from tracks (using either idiosyncratic features or discriminant functions) was often impossible due to cattle and extreme weather conditions. Thus, we conclude that a combination of photographic captures and identification from tracks provided the most complete and defensible enumeration of jaguars in northeastern Sonora. Because rugged topography, hard soils, absence of roads, and harsh weather conditions make it less reliable to use only one technique, using 2 different techniques allowed detection of a greater number of jaguars and pumas and thus a better understanding of the population status and trend.

Karanth et al. (2003) and Miller (2004) concluded that identification of individual felids such as Asiatic tigers (Panthera tigris) and jaguars from tracks was not feasible or reliable due to several variables which cannot be controlled, such as different substrates and small sample sizes collected from each individual. Consequently, Karanth et al. (2003) recommended that track surveys not be used for conservation decisions due to the lack of reliability of the technique and recommended camera-trapping as an alternative. However, we found that track surveys, in conditions such as northeastern Sonora, whether based on idiosyncratic features or discriminant analysis, corroborated photographic identification and detected more individuals of all age classes than did camera traps. Individual identification from idiosyncratic features of frontfoot was also supported by successful classification of species and sex (and, to a lesser extent, individuals) by discriminant analysis of hindfeet. Additionaly, when identification from idiosyncratic features and discriminant analysis differed, the discriminant function always assigned individuals to the other species, an error not present when simply identifying species by track shape (Aranda 2000). Sample sizes were also adequate despite the constraints we placed on tracks included in analyses; we detected and measured tracks of individual jaguars from 2-33 times $(\overline{\mathrm{X}}=12 ; \mathrm{SE}=3)$ and 2-14 $(\overline{\mathrm{X}}=8 ; \mathrm{SE}=1)$ times for pumas. Most importantly, camera-traps missed jaguars (and pumas) detected by track traps, but no jaguars (or pumas) that were photographed were not previously captured in track traps. Thus, camera trapping and track surveys in combination provided a much more complete enumeration of the jaguar and puma population. Similarly, Karanth \& Nichols (1998) only detected tiger cubs from track surveys, as cubs were not photographed at camera traps.

Miller (2004) concluded that it was not possible to differentiate jaguars and pumas from tracks. In contrast, we found that following a protocol of only collecting tracks from flat areas, dirt or silt substrates, and at least 1 front and 1 hindfoot of the same individual, both qualitative (idiosyncratic features) and quantitative (4 basic mea- 
surements) analyses showed that tracks could reliably identify species and gender of jaguars and pumas with a range of 74-87\% accuracy. Our results supported those results of Isasi-Catalá \& Barreto (2008), who differentiated individual jaguars using discriminant analysis. We were also able to differentiate species and sex using only 4 simple measurements, as compared to $\geq 15$ in previous analyses (Smallwood \& Fitzhugh 1993, Riordan 1998, Sharma et al. 2005). Moreover, discriminant analysis showed the potential to correctly classify hindfoot tracks to individuals as well, facilitating and corroborating the ability of idiosyncratic features of frontfoot tracks to identify individuals as well as species and sex.

Use of idiosyncratic features of frontfoot to identify individual jaguars and pumas in our study area was supported by the results of both photographic recaptures and discriminant analysis. Jaguar tracks frequently showed readily identifiable diagnostic characteristics on their frontfoot (Table 2; Figures 3 and 4). Predators such as jaguars primarily use their forefeet to subdue their prey and in territorial confrontations, and can sustain injuries by being caught in predator control traps. Thus, they were more likely to show deformations in their frontfoot morphology such as bent toes, displaced toes, disfigured toes, and disfigured pads (Figures 3, 4). In contrast, we found that individual pumas were more difficult to identify by idiosyncratic characteristics of their frontfoot. Identification of individuals from tracks was also easier for jaguars than pumas because the larger and rounder shape of the jaguar forefoot allowed observers to more readily detect diagnostic characteristics. Anecdotally, the low numbers of jaguars in our study area likely allowed for greater familiarity with, and consequently easier recognition of their tracks. After several years (1999-2004) of tracking the same individuals, recognizing their tracks was not difficult.

Total numbers of jaguars present varied over our study, as did the individuals in the population (Table 1). Of the original 6 jaguars identified from 1999-2003, only 3 were detected by 2004 and none were seen in 2005, when 4 new jaguars were identified. Thus, the jaguar population in northeastern Sonora showed a high turnover of individuals and significant year-to-year variation in population size. This may be due to high rates of immigration and emigration as well as continued illegal killing of jaguars due to livestock conflicts (Rosas-Rosas et al. 2008). Regardless, the turnover and large annual variation in numbers makes frequent monitoring of this population critical if it is to persist in northeastern Sonora. Moreover, the high turnover, if not solely due to illegal killing, suggests that individual survival or suitability of habitats may be limited by other environmental factors. Relatedly, the population may simply be transitory in nature, although lack of evidence of establishment of other populations further away from core jaguar habitats in the Sierra Madre Occidental argues against this. Regardless, efforts to determine the fates of individual jaguars in this population are needed to judge the viability of the population for long-term conservation of jaguars in northeastern Sonora. 
Lastly, the estimated jaguar density reported in our study $\left(1 / 100 \mathrm{~km}^{2}\right)$ was less than in Jalisco, Mexico (2/100 km²; Nuñez et al. 2002), the Maya Biosphere Reserve, Guatemala (2/100 km²; Novack 2003), the Yucatan peninsula (3-7/100 km²; Chávez et al. 2007; Faller et al. 2007), Campeche, Mexico (1/27 km²; Aranda 1998), and the Cockscomb Basin, Belize $\left(9 / 100 \mathrm{~km}^{2}\right.$; Silver et al. 2004). The lower density in northeastern Sonora probably reflects its location at the fringe of jaguar range, where fluctuations of jaguar populations would be expected due to resource variability (Urness 1981) and illegal killing due primarily to livestock conflicts (Rosas-Rosas et al. 2008, 2010).

Jaguars are endangered and protected in Mexico (SEMARNAT 2001), and the Sierra Madre Occidental is considered a priority area for long-term jaguar conservation (Sanderson et al. 2002). The high turnover of individuals, the large year-to-year fluctuations in population size, and the low jaguar density all make the viability of this northernmost breeding population of jaguars uncertain. Thus, it is critical that this population be carefully monitored. Because of inherent limitations with either method, we recommend that monitoring include both photographic camera trapping and track surveys, as use of multiple methods provide valuable corroboration of minimum estimates not possible with use of one technique alone. If constraints preclude use corroborating techniques, we recommend track surveys for use in northeastern Sonora because of the ability to more thoroughly enumerate individuals, because conditions are logistically difficult to efficiently conduct camera-trapping, and track surveys consistently identified all sex and age classes of the population. However, we caution that this data be rigorously collected and carefully evaluated, as in our analysis, by managers highly familiar with jaguars and pumas. Further development and testing of discriminant functions on a larger number of known individual could significantly facilitate this approach, although discriminant functions are best developed locally because of morphological variation in mean size of jaguars and puma throughout their range (Seymour 1989, Iriarte et al. 1990). While camera-trapping alone in other areas such as portions of Central and South America may be an adequate technique, many of these areas have much gentler terrain and greater access, which facilitates visiting camera stations (Silver et al. 2004). In our study, approximately $360 \mathrm{~km}^{2}$ were monitored using 26 camera stations. Camera-trapping may have been more successful if only $200 \mathrm{~km}^{2}$ had been monitored for a period of 45 days, and then cameras moved to the other $200 \mathrm{~km}^{2}$ for another 45 days. This may have allowed more frequent monitoring of cameras by personnel and allowed for additional sets of cameras in areas where cattle were concentrated. Additionally, sole use of digital cameras with large memory cards could mitigate some of the problems we experienced, such as cattle triggering camera-traps, by allowing much faster camera cycling intervals. 
ACKnowledgments. We thank the Mexican National Council of Science and Technology (CONACyT) for providing a doctoral scholarship to O. C. Rosas-Rosas, and the Jaguar Conservation Program of the Wildlife Conservation Society, Summerlee Foundation, Secretary of Natural Resources of Mexico (SEMARNAT), the municipality of Nacori Chico, Sonora, Mexico, COLPOS, and the New Mexico State University Agricultural Experiment Station for funding and other support. In addition, we also acknowledge all project personnel, volunteers, and ranchers for their aid in field research activities.

\section{LITERATURE CITED}

Aranda, M. 1998. Densidad y estructura poblacional del jaguar (Panthera onca) en la reserva de la Biosfera Calakmul, Campeche, México. Acta Zoológica Mexicana (n. s.), 75: 199-201.

Aranda, M. 2000. Huellas y otros rastros de los mamíferos grandes y medianos de México. Instituto de Ecología A.C., Xalapa, Veracruz.

Beier, P. \& S. C. Cunningham. 1996. Power of track surveys to detect changes in cougar populations. Wildlife Society Bulletin, 24: 540-546.

Brown, D. E. 1982. Biotic communities of the American southwest-United States and Mexico. Desert Plants, 4: 1-4.

Ceballos, G., C. Chávez, List R. \& H. Zarza. 2007. Conservación y manejo del jaguar en México: estudios de caso y perspectivas. Conabio-Alianza WWF/Telcel-Universidad Nacional Autónoma de México, México.

Chávez, C., G. Ceballos \& M. Amín. 2007. Ecología poblacional del jaguar y sus implicaciones para la conservación en la Península de Yucatán, pp. 91-100. In: Ceballos G., C. Chávez, R. List \& H. Zarza (Eds.). Conservación y manejo del jaguar en México: estudios de caso y perspectivas. Conabio-Alianza WWF/TELCEL-Universidad Nacional Autónoma de México, México.

Faller, J. C., C. Chávez, S. Johnson \& G. Ceballos. 2007. Densidad y tamaño de la población de jaguar en el noreste de la Península de Yucatán, pp. 111-122. In: Ceballos G., C. Chávez, R. List \& H. Zarza (Eds.). Conservación y manejo del jaguar en México: estudios de caso y perspectivas Conabio-Alianza WWF/Telcel-Universidad Nacional Autónoma de México, México.

Federal Register. 1997. Final rule to extend endangered status for the jaguar in the United States, 62: 39147-39157.

Glenn, W. 1997. Eyes of fire; close encounters with a borderland jaguar. University of Texas at El Paso Press, TX.

Hall, E. R. 1981. The Mammals of North America. Second Edition. John Wiley and Sons, New York.

Hornocker, M. 1969. Winter territoriality in mountain lions. Journal of Wildlife Management, 33: 457464.

Iriarte, J. A, Franklin, W., Johnson W. \& K. Redford. 1990. Biogeographic variation of food habits and body size of the America puma. Oecologia, 85: 185-190

Isasi-Catalá, E. \& G.R. Barreto. 2008. Identificación de individuos de jaguares (Panthera onca) y pumas (Puma concolor) a partir de morfometría de sus huellas (Carnivora: Felidae). Revista de Biología Tropical, 56: 1893-1904.

Karanth, U. K. 1995. Estimating tiger Panthera tigris populations from camera-trap data using capturerecapture models. Biological Conservation, 71: 333-338.

Karanth, U. K. \& J. D. Nichols. 1998. Estimation of tiger densities in India using photographic captures and recaptures. Ecology, 79: 2852-2862.

Karanth, U. K. \& J. D. Nichols. 2002. Monitoring tigers and their prey; a manual for researchers, managers and conservationist in tropical Asia. Centre for Wildlife Studies, India. 
Karanth, K. U., J. Nichols, J. Seidensticker, E. Dinerstein, J. L. D. Smith, C. McDougal, A. J. T. Johnsingh, R. S. Chundawat \& V. Thapar. 2003. Science deficiency in conservation practice: the monitoring of tiger in India. Animal Conservation, 6:141-146.

Karanth, K. U., R. S. Chundawat, J. D. Nichols \& N. S. Kumar. 2004. Estimation of tiger densities in the tropical forests of Panna, Central India, using photographic capture-recapture sampling. Animal Conservation, 7: 285-290.

Kelly, M. J., A. J. Noss, M. S. DiBertti, L. Maffei, R. L. Arispe, A. Paviolo, C. D. De Angelo \& Y. E. DiBlanco. 2008. Estimating puma densities from camera trapping across three study sites: Bolivia, Argentina, and Belize. Journal of Mammalogy, 89: 408-418.

Logan, K. A., L.L. Sweanor, T.K. Ruth \& M. Hornocker. 1996. Cougars of the San Andres Mountains, New Mexico. Final Report. Federal Aid in Wildlife Restoration, Project W-128-R. New Mexico Department of Game and Fish, Santa Fe, New Mexico.

López-González, C. \& D. E. Brown. 2002. Status and distribution of the jaguar in Sonora, Mexico, pp. 379-392 In: Medellín, R.A., C. Equihua, C. L. B. Chetkiewicz, P. G. Crawshaw Jr., A. Rabinowitz, K. H. Redford, J. G. Robinson, E. W. Sanderson \& A. B. Taber (Eds.). El jaguar en el nuevo milenio. Universidad Nacional Autónoma de México, Wildlife Conservation Society, Fondo de Cultura Económica. México, D.F.

Marshall, J. T., Jr. 1957. Birds of pine-oak woodland in southern Arizona and adjacent Mexico. Pacific Coast Avifauna, 32: 1-125.

McCain, E. B., \& J. L. Childs. 2008. Evidence of resident jaguars (Panthera onca) in the southwestern United States and the implications for conservation. Journal of Mammalogy, 89: 1-10.

Miller, C. M. 2004. Jaguar track measurements: Investigation of a potential survey method. Final Report. Wildlife Conservation Society, New York.

Morrison, F. D. 1990. Multivariate Statistical Methods. 3rd Edition. McGraw-Hill Publishing Company, New York.

Novack, A. J. 2003. Impacts of subsistence hunting on the foraging ecology of jaguar and puma in the Maya Biosphere Reserve, Guatemala. Thesis, University of Florida, Gainsville, Florida.

Nuñez, R., B. Miller, \& F. Lindzey. 2002. Ecología del jaguar en la reserva de la biosfera ChamelaCuixmala, Jalisco, México, pp. 107-126 In: Medellín, R.A., C. Equihua, C. L. B. Chetkiewicz, P. G. Crawshaw Jr., A. Rabinowitz, K. H. Redford, J. G. Robinson, E. W. Sanderson, \& A. B. Taber (Eds.). El jaguar en el nuevo milenio. Universidad Nacional Autónoma de México, Wildlife Conservation Society, and Fondo de Cultura Económica. México, D.F.

Rabinowitz, A. R. \& B. G. Nottingham, Jr. 1986. Ecology and behaviour of the jaguar (Panthera onca) in Belize, Central America. Journal of Zoology, 210: 149-159.

Riordan, P. 1998. Unsupervised recognition of individual tigers and snow leopards from their footprints. Animal Conservation, 1: 253-262.

Rosas-Rosas, O. C., R. Valdez, L.C. Bender \& D. Daniel. 2003. Food habits of pumas in northwestern Sonora, Mexico. Wildlife Society Bulletin, 31: 528-535.

Rosas-Rosas, O.C., L.C. Bender \& R. Valdez. 2008. Jaguar and puma predation on cattle calves in northeastern Sonora, Mexico. Rangeland Ecology and Management, 61:554-560.

Rosas-Rosas, O.C., L.C. Bender \& R. Valdez. 2010. Habitat correlates of jaguar kill sites of cattle in northeastern Sonora, Mexico. Human-Wildlife Conflicts, 4: 113-121.

Salmon, W. C. 1979. The foundations of scientific inference. University of Pittsburgh Press, Pittsburgh, Pennsylvania.

Salom-Pérez, R., E. Carrillo, J. C. Sáenz \& J. Mora. 2007. Critical condition of jaguar Panthera onca population in Corcovado National Park, Costa Rica. Oryx, 41: 51-56. 
Sanderson, E. W., C. L. B. Chetkiewicz, R.A. Medellin, A. Rabinowitz, K.H. Redford, J. G. Robinson \& A. Taber. 2002. Prioridades geográficas para la conservación del jaguar, pp. 601-628. Medellín, R.A., C. Equihua, C. L. B. Chetkiewicz, P. G. Crawshaw Jr., A. Rabinowitz, K. H. Redford, J. G. Robinson, E. W. Sanderson \& A. B. Taber (Eds.). El jaguar en el nuevo milenio. Universidad Nacional Autónoma de México, Wildlife Conservation Society, and Fondo de Cultura Económica. México, D.F.

Schaller, G. B., \& P. G. Crawshaw. 1980. Movement patterns of jaguars. Biotropica, 12: 161-168.

SEMARNAT. 2001. Norma Oficial Mexicana (NOM-059-Ecol) que determina las especies y subspecies de flora y fauna silvestres, terrestres y acuáticas en peligro de extinción, amenazadas, raras y sujetas a protección especial que establece especificaciones para su protección.

Seymour K. 1989. Panthera onca. Mammalian species, 340:1-9

Silver, S. C., L.E.T. Ostro, L.K. Marsh, L. Maffei, A.J. Noss, M.J. Kelly, R.B. Wallace, H. Gomez \& G. Ayala. 2004. The use of camera traps for estimating jaguar Panthera onca abundance and density using capture/re-capture analysis. Oryx, 38: 1-7.

Sharma, S., Y. Jhala \& V. B. Sawarkar. 2005. Identification of individual tigers (Panthera tigris) from their pugmarks. Journal of Zoology, 267: 9-18.

Smallwood K. S. \& E. L. Fitzhugh. 1993. A rigorous technique for identifying individual mountain lions Felis concolor by their tracks. Biological Conservation, 65: 51-59.

Urness, P. J. 1981. Desert and chaparral habitats; food habits and nutrition, pp.347-287 In: O.C. Wallmo (Ed.). Mule and black-tailed deer of North America. University of Nebraska Press, Lincoln, Nebraska. 